\title{
DESIGN PARA AÇÃO SOCIAL E SUSTENTABILIDADE: INCENTIVO EM CURSO DE DESIGN
}

\author{
Pazmino, Ana Veronica; Dra; \\ Universidade Federal de Santa Catarina - UFSC \\ ana.veronica@ufsc.br
}

\begin{abstract}
Resumo: O artigo apresenta a aplicação da estratégia de ensinagem por projeto como meio pedagógico para incentivar a ação social e sustentável dos educandos na disciplina de metodologia de projeto no curso de Design da Universidade Federal de Santa Catarina. O trabalho mostra a fundamentação teórica do design e a sustentabilidade e da estratégia de ensinagem por projeto. Posteriormente, é descrita a ação pedagógica, as técnicas e ferramentas de projeto aplicadas na disciplina, e também émostrado um resumo do desenvolvimento de produtos gráficos de sensibilização social e ambiental dos alunos da disciplina. Finalmente são descritos os resultados qualitativos da ação pedagógica.
\end{abstract}

Palavras-chave: Ensino de design, Estratégia de Ensinagem, Metodologia de projeto, Sustentabilidade.

\begin{abstract}
The paper presents the application the strategy of teaching for design as a pedagogical tool to foster the social and sustainable share of students in the discipline of design methodology in Design course at the Federal University of Santa Catarina. The work shows the theoretical basis for the design and sustainability and the design of teaching and strategy. Subsequently, it describe the pedagogical action, techniques and design tools applied in the discipline, and is also shown a summary of the development of graphic products of social and environmental awareness of students of the discipline. Finally it describes the qualitative results of the pedagogical action.
\end{abstract}

Keywords: Teaching design, teaching strategy, methodology project design, Sustainability.

\section{INTRODUÇÃO}

$\mathrm{Na}$ década de 60 os movimentos relacionados ao meio ambiente vieram à tona já seja, tanto pela percepção de cientistas dos impactos provocados pelo ser humano, como pela divulgação dos problemas ambientais. Ao longo de quatro décadas tentou- 
se modificar o Paradigma Social Dominante PSD que tem uma perspectiva antropocêntrica e anti-ecologista pelo Novo Paradigma Ambiental (NPA) e o Novo Paradigma Ecológico (NPE), que consideram que embora o ser humano tenha características excepcionais, tais como a tecnologia e a cultura, são dependentes das outras espécies do ecossistema.

O campo do design ao longo destes 40 anos teve publicações interessantes de designers e teóricos engajados na problemática social e ambiental. Também ao longo desses anos, foram desenvolvidos produtos e serviços visando "minimizar os impactos ambientais" no âmbito social, pouca ação tem sido feita. Consequentemente o designer continua sendo "parte do problema".

Em parte, porque o designer não tem nem legitimidade, nem os instrumentos para obrigar por meio de (leis) ou convencer (considerações morais) qualquer um a modificar o comportamento. Mas também, porque o designer desconhece e na maioria das vezes, tem uma visão míope da realidade social e ambiental.

Cabe então no ensino de design, desenvolver o espírito crítico e ampliar a visão dos educandos para os problemas sociais e ambientais, de forma que, apliquem a razão de serem criadores de novos produtos e comunicadores éticos e responsáveis. Isso implica reformular valores que tem sido impostos pela sociedade.

\section{DESIGN E SUSTENTABILIDADE}

Na década de 70, (PAPANEK, 1977) já questionava a profissão do designer da maneira como se apresentava e exigia uma responsabilidade moral e social por parte deste profissional. Argumentava que numa era de produção em massa, o design havia se tornado uma ferramenta poderosa na configuração de ferramentas e ambientes para o homem e ressaltava a importância de se compreender as necessidades básicas dos seres humanos e sua relação com o design.

O autor declarava também, que era preciso projetar dentro de um contexto social. Seu papel foi o de cobrar dos designers um maior engajamento e, sobretudo, a criação de um design para atender às necessidades sociais.

\footnotetext{
No repertório das capacidades e talentos de um designer incluem-se: [...]5. O talento para combinar as rigorosas considerações técnicas da forma criada com a preocupação dos fatores sociais e humanos e da harmonia estética; 6 . A sabedoria para prever as consequências ambientais, ecológicas, econômicas, e políticas provocadas pelo design [...] (PAPANEK, 1995)
}

Porém, ainda encontramos autores que mostram que o design não prevê as consequências e não considera os fatores ambientais e sociais. Segundo (MCDONOUGH e BRAUNGART, 2005) A intenção do design consiste em criar um produto atrativo que seja acessível que cumpra com as regulamentações, que tenha um desempenho aceitável e dure o suficiente para satisfazer as necessidades dos mercados. Porém, embora os produtos satisfaçam os desejos do fabricante e dos consumidores, não estão projetados para beneficiar a saúde humana e ecológica.

Para Manzini (2008) Os designers têm sido, e ainda são, "parte do problema" das condições atuais do planeta. Para o autor "Designers podem e devem ter outro papel, tornando-se, portanto, parte da solução".

A problemática ambiental mostra fatores como explosão demográfica, diminuição dos recursos naturais, aumento da poluição, desequilíbrios ecológicos e 
climáticos como assuntos que se tornaram evidentes, porém, a problemática atual, não está apenas relacionada à questão ambiental. O termo desenvolvimento sustentável evidenciou problemas relacionados à dimensão social. Pobreza, desigualdade, perda ou falta da qualidade de vida, violência entre outros.

A abrangência do tema da sustentabilidade e das dimensões envolvidas já foi mencionada no conceito das três ecologias que foi formulada por Félix Guattari, 2007 (filósofo, psicanalista e político Francês) A ecologia do meio ambiente é aquela relativa às transformações tecnológicas e econômicas da modernidade relacionadas aos desequilíbrios ecológicos que ameaçam a vida no planeta. A ecologia das relações sociais diz respeito à deterioração da qualidade de vida. A ecologia da subjetividade humana relaciona-se com os comportamentos que dirigem a vida familiar doméstica, a vida das relações como um todo e os comportamentos empobrecidos.

As três ecologias tratam do ambiente inteiro para dentro e além de nós. Uma visão ecológica abrangente que considera um ambiente de reciprocidade, onde a alteração de um único elemento pode trazer transformações para o conjunto, colocando em risco o equilíbrio de tudo ou do "todo".

Nessa abordagem se exige que os designers e produtores, pensem em como favorecer uma transição que atinja o objetivo sustentável, um processo articulado de qualidade social, econômica e ambiental.

\section{ESTRATEGIA DE ENSINAGEM POR PROJETO}

Existe uma diferença entre aprender e apreender, embora nos dois verbos exista a relação entre o sujeito e o conhecimento, advoga Anastasiou (2006). 0 apreender significa segurar, prender, pegar, assimilar mentalmente, entender, compreender. Não se trata de um verbo passivo; pois para apreender é preciso agir, exercitar-se, informar-se, tomar para si, apropriar-se, entre outros fatores. Já o verbo aprender, significa tomar conhecimento, reter na memória mediante estudo, receber a informação. É importante distinguir os termos e os objetivos do professor. Se for apenas que o aluno receba a informação, uma aula de exposição de tópicos, tradicional é suficiente. Já se, o professor busca a apropriação do conhecimento pelo aluno, é preciso que o professor escolha estratégias diferenciadas de ensinagem.

Anastasiou (2006) ressalta que as estratégias visam à consecução de objetivos, portanto, há que se ter clareza sobre aonde se pretende chegar naquele momento com o processo de ensinagem.

Masetto (2001) salienta que uma atividade em projetos é uma das mais completas e envolventes estratégias pedagógicas. Já que a elaboração de um projeto sempre está relacionada a uma situação profissional, a uma situação real em que o grupo de alunos pode identificar uma situação problemática, descrevê-la, levantar perguntas, fazer o diagnóstico do problema, levantar aspectos teóricos que merecem estudos e aprofundamentos, selecionar estratégias ou procedimentos, buscar soluções.

No ensino por projetos parte-se de uma didática prática em que o professor não corre o risco de trazer surpresas ao final do semestre ou do ano, porque ao utilizar projetos necessariamente vai manter os alunos informados sobre seus progressos e suas dificuldades. A avaliação contínua aumenta com o ensino participativo como 
interesse do aluno pelo projeto, que contem a ação como elemento chave, motivando a aprendizagem.

O trabalho por projetos exige dos alunos fortalecerem a pesquisa e o trabalho em equipe; requer que ele partilhe ideias, tome decisões e não seja o autor individual da solução, pois esta é compartilhada. Segundo (PAZMINO, 2010) Este tipo de abordagem é muito adequado para a disciplina de metodologia de projeto, já que a atividade da profissão do designer é basicamente uma atividade projetual. A aplicação do ensino por projeto como atividade pedagógica mostra que o trabalho em equipe fica fortalecido e a individualidade se transforma em parceria.

Segundo Pazmino (2010), o contato com a realidade concreta da aula prática propicia que o aluno valorize a teoria. Os alunos necessitam para exercer sua profissão como designers, de uma consistente preparação teórica, vinculada à atividade prática de desenvolver projetos. Assim, na disciplina de Metodologia de projeto junto devemse aplicar várias estratégias de ensinagem entre elas a "Estratégia por Projetos" que é considerada uma das mais completas atividades pedagógicas coletivas. A elaboração do projeto está relacionada à situação profissional do designer, a uma situação real para identificar e satisfazer as necessidades do público.

A estratégia identifica um problema de projeto e a partir dessa problematização os alunos em equipes devem desenvolver produtos para solucionar o problema. Para isto, é interessante que sejam formadas equipes, as mesmas que devem realizar as seguintes atividades: coleta de dados, análise de informações, síntese de dados, seleção de métodos a serem aplicados, busca criativa de soluções e resolução do problema de projeto.

Aplicar a Estratégia por projeto em sala de aula permite que o aluno, fazendo parte de uma equipe, experimente uma situação próxima do real. Isto exige o trabalho em grupo, a partilha de ideias, o respeito às ideias dos outros, a busca de um consenso em prol de uma solução melhor. O quadro 1 mostra a descrição da estratégia por projetos.

\section{Quadro 1 Estratégia por projetos}

\begin{tabular}{|c|c|}
\hline DESCRIÇÃO & $\begin{array}{l}\text { É uma atividade coletiva que visa a elaboração de um projeto relacionada } \\
\text { com a prática profissional e uma situação real. O professor conduz os } \\
\text { alunos a realizarem atividades para solucionar o problema de projeto. }\end{array}$ \\
\hline $\begin{array}{l}\text { OPERAÇÕES DE } \\
\text { PENSAMENTO } \\
\text { (Predominantes) }\end{array}$ & $\begin{array}{l}\text { Obtenção e organização de dados/Análise, Aplicação de } \\
\text { métodos/Pesquisas/Tomada de decisão/Crítica/Busca de soluções. }\end{array}$ \\
\hline $\begin{array}{l}\text { DINÂMICA DA } \\
\text { ATIVIDADE }\end{array}$ & $\begin{array}{l}\text { O professor escolhe um tema de projeto (necessidade ou problema) este } \\
\text { deve estar de acordo com o nível de desenvolvimento do grupo em relação } \\
\text { a habilidade, conhecimento de métodos de projeto e experiência prática } \\
\text { dos alunos. } \\
\text { Dividir o grupo em equipes de forma que todos realizem o projeto e que os } \\
\text { resultados sejam parte da avaliação da equipe. } \\
\text { 1. Identificar o problema: dados sobre as necessidades do cliente; } \\
\text { 2. Coleta de informações: levantamento de dados para visualizar e } \\
\text { solucionar o problema; } \\
\text { 3. Análise dos inputs e outpus: aplicação de métodos de projeto; } \\
\text { 4. Síntese: agrupamento das informações relevantes; } \\
\text { 5. Solucionar o problema de forma criativa. }\end{array}$ \\
\hline AVALIAÇÃO & $\begin{array}{l}\text { Apresentação das atividades do projeto, troca de informações com os } \\
\text { outros participantes e com a turma. Produção escrita em forma de } \\
\text { relatório. }\end{array}$ \\
\hline
\end{tabular}

Fonte: Pazmino, 2010 p. 350 
A estratégia auxilia no desenvolvimento da capacidade criativa do aluno fundada na análise e síntese de informações, na sua elaboração de saberes e no trabalho em equipe. Para isto, o docente deve estimular a curiosidade, evitar a preguiça mental, evitar os bloqueios mentais, auxiliar os alunos no entendimento da teoria e sua aplicação na prática, induzir a soluções criativas, estimular a apresentação oral para os colegas e produção escrita dos resultados. A forma de avaliação desta estratégia utiliza a apresentação oral, na qual os alunos em equipes apresentam o processo de realização do projeto por meio de fases, etapas, tarefas e métodos de projeto.

\section{DESENVOLVIMENTO}

A disciplina de Metodologia de Projeto na UFSC é uma matéria introdutória oferecida no segundo semestre do curso de design. Conta com 60 alunos e 54 horas aula.

No segundo semestre de 2013 os alunos em equipes de três foram estimulados a realizar ao longo do semestre um projeto para desenvolver um produto (objeto, gráfico, animação etc.) objetivando informar ou sensibilizar o público em relação às problemáticas sociais e ambientais: Água, Alimentação, Energia, Mobilidade, Lixo eletrônico, Consumo, Lixo orgânico, Lixo reciclável, Pobreza, Poluição, Perda da Biodiversidade, outras problemáticas também poderiam ser sugeridos pelos alunos.

Seguindo o plano de aula e aplicando os conceitos e práticas com algumas técnicas e ferramentas de projeto que constam no Livro "Como se Cria" de Pazmino, 2013, tais como: Equipe de projeto, Mapa mental ou conceitual, Análise das relações, Análise diacrônica, Análise sincrônica, Lista de Verificação, Pesquisa das necessidades do consumidor, Persona e Cenário, Análise funcional, Diagrama de Ishikawa, Painel conceitual e visual, Matriz de decisão, Memorial descritivo entre outras, as equipes foram desenvolvendo os produtos. Para facilitar o acompanhamento dos projetos as equipes foram denominadas por números de 1 a 21.

A turma desenvolveu 21 produtos, a seguir é mostrado um resumo de três projetos de forma a perceber o resultado da prática pedagógica.

\subsection{Pobreza e os fatores que a influenciam}

Por meio de pesquisas, os alunos da Equipe 9 perceberam que pobreza é um termo amplo e complexo, isto é, pobreza pode ser definida de diversas maneiras. No trabalho os alunos optaram pela definição de que a pobreza representa a carência de recursos econômicos e das necessidades básicas como, por exemplo, alimentação, vestuário, cuidados básicos de saúde e moradia.

No Brasil segundo G1 (web) dados do IBGE de 2010 mostram que o Brasil tem 16,27 milhões de pessoas em situação de extrema pobreza (pessoas vivem com até $\mathrm{R} \$ 70,00$ por mês), o que representa $8,5 \%$ da população.

Podem-se compreender os fatores que atualmente perpetuam a pobreza e procurar formas de amenizar e resolver a questão. Cinco principais fatores de manutenção da pobreza: ignorância, doença, desonestidade, dependência e apatia.

Após a pesquisa inicial os alunos decidiram que o projeto seria informar e sensibilizar em relação aos fatores que influenciam a pobreza foi aplicado um questionário com o público previamente estabelecido e devidamente segmentado. 
A figura 1 mostra o infográfico com o resultado do questionário.

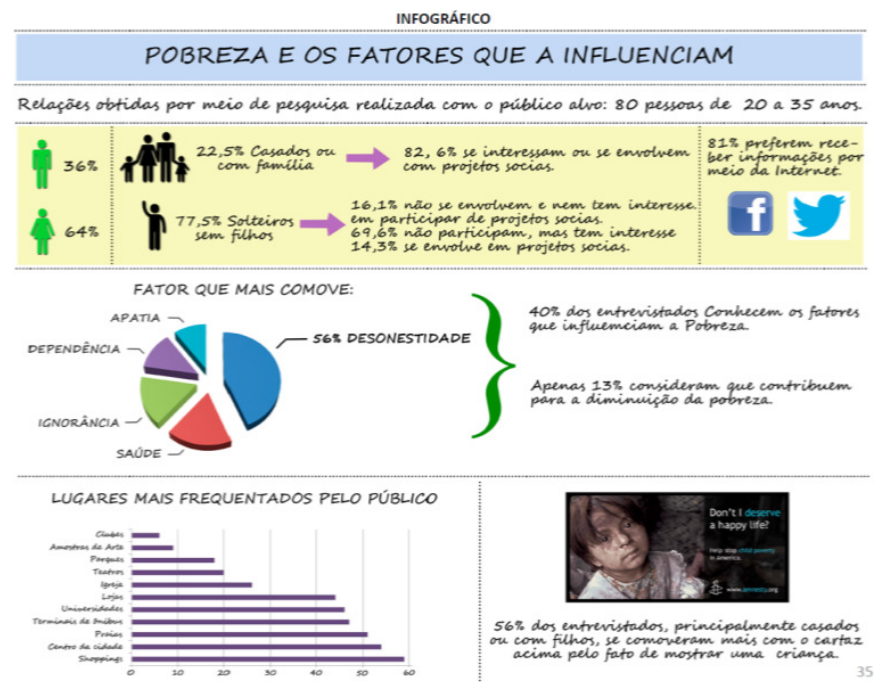

Figura 1 Infográfico da pesquisa

Fonte: GOBBI et al. 2013

A seguir na Figura 2 uma parte da análise sincrônica de cartazes ou páginas de revista que tratam da pobreza.

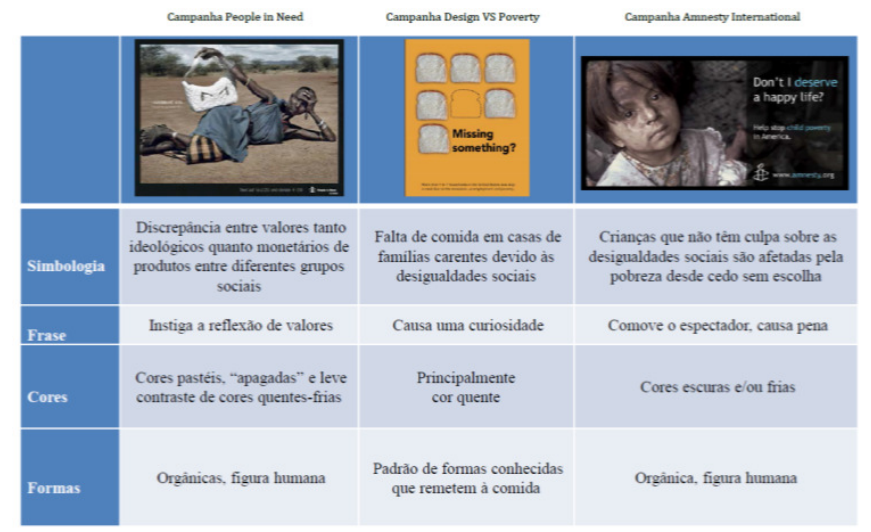

Figura 2 Análise Sincrônica de cartazes

Fonte: GOBBI et al. 2013

Na fase de síntese do projeto a Equipe decidiu por meio da Análise Funcional e do Diagrama de Ishikawa decidir que iriam produzir um cartaz ou um vídeo curto com a imagem de uma criança em uma situação precária. Na foto poderiam utilizar a técnica "cinemagraph", em que uma imagem é construída por meio de uma técnica de animação sutil de pequenos detalhes de fotos.

Dessa forma, as alternativas podiam gerar vídeos de curta duração ou apenas painéis dinâmicos ou até estáticos. Após a geração de alternativas o grupo produziu a imagem fotográfica com uma criança que foi maquiada e colocada num contexto de sujeira. Criaram imagens fotográficas de criança em situações de pobreza - já que por meio das pesquisas elas são as que mais sensibilizam o público sobre o assunto. 0 cartaz apresenta um texto que acompanha as imagens para explicar melhor o tema da pobreza, e para sensibilizar as pessoas. A Figura 3 apresenta um dos cartazes. 


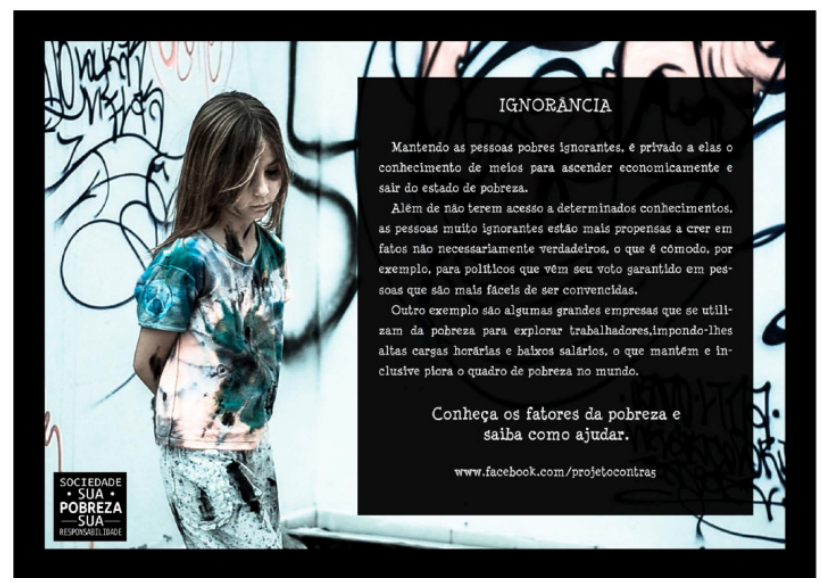

Figura 3 Cartaz sobre o fator ignorância que influencia a pobreza Fonte: GOBBI et al. 2013

O projeto visou sensibilizar, emocionar e informar o público a respeito das questões que envolvem a pobreza (apatia, desonestidade, dependência, ignorância, doença). São cinco cartazes, informando em cada um deles os cinco fatores por meio de um texto explicativo e a imagem de uma criança em situação precária. 0 projeto criou também um vídeo com as imagens da criança e publicado no facebook.

\subsection{Poluição na água e no ambiente (Lagoa da Conceição)}

Os alunos da Equipe 17 levantaram que nos últimos anos o número de habitantes na região da Bacia da Lagoa da Conceição (Florianópolis/SC) vem crescendo desordenadamente e sem planejamento. No entanto, as pessoas que procuram a região para morar ou apenas passar a temporada de verão, não percebem o tamanho do impacto ambiental que provocam com a poluição na Lagoa. Hoje, a Lagoa acumula diversos problemas ambientais causados por esgotos domésticos, gorduras, embarcações, lixo, assoreamento e acidificação.

Segundo o site da Alesc, hoje na Lagoa da Conceição, $40 \%$ do esgoto que é produzido na região é despejado sem nenhuma espécie de tratamento, e o despejo da água pluvial se encontra em situação irregular nas proximidades da Lagoa. Existe ainda o problema com a salinidade da água na bacia da lagoa por conta da abertura permanente da barra, acontecendo a troca de água salgada e doce frequentemente. Já que esse processo de troca de águas é algo natural, quando ocorre a alteração antrópica, causa transtornos nas comunidades bióticas, e pode até extinguir algumas espécies.

A maior parte dos estudos confirma os problemas esperados. Devido à grande quantidade de esgoto despejado sem tratamento, há elevada concentração de coliformes fecais em diversos pontos da Lagoa. Há também grande quantidade de metais pesados como Zinco Chumbo, Níquel, Cromo e Cádmio, estes são oriundos de tintas e óleos das atividades náuticas. Estes níveis de poluição impedem a balneabilidade em diversas regiões da Lagoa da Conceição.

Há mais de 10 anos já foi observado que a Lagoa precisava de um plano de conservação, monitoramento e recuperação. Entretanto, por não haver um monitoramento contínuo das condições da Lagoa, a implementação de qualquer plano 
de preservação fica prejudicada, uma vez que não se sabe como o ecossistema irá reagir.

Após a pesquisa inicial os alunos decidiram que o projeto seria informar e sensibilizar os moradores e turistas em relação à poluição da Lagoa. Aplicaram um questionário com o público previamente estabelecido e devidamente segmentado.

A Figura 4 mostra um gráfico com o resultado de uma das perguntas do questionário.

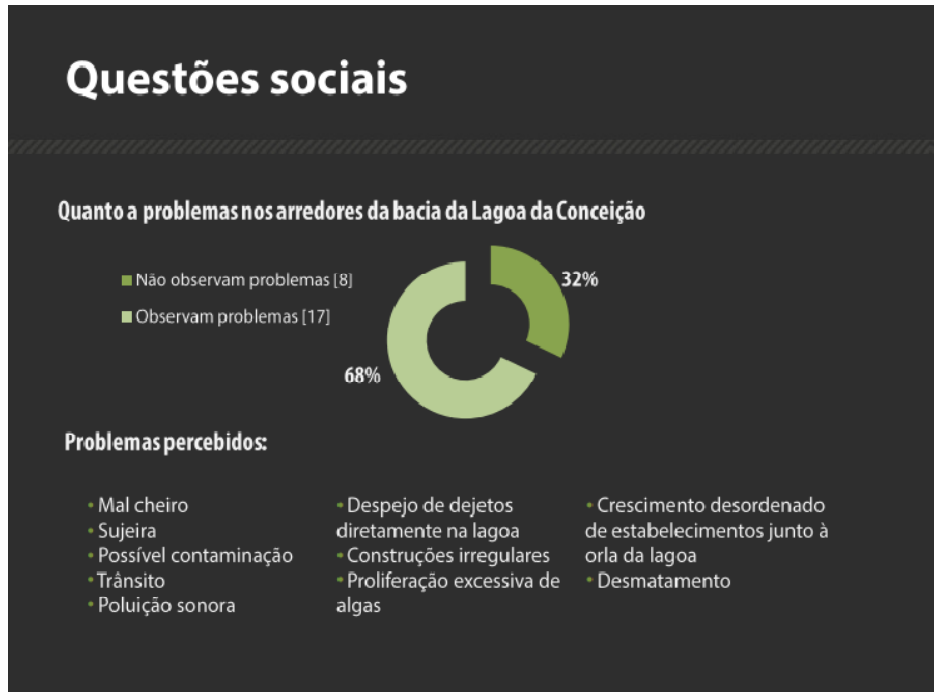

Figura 4 Problemas percebidos pelos moradores e turistas

Fonte: NETO et al. 2013

Na pesquisa de cartazes que tratam de assuntos relacionados à problemática ambiental, a Equipe como mostra a Figura 5 fez uma análises de cartazes.

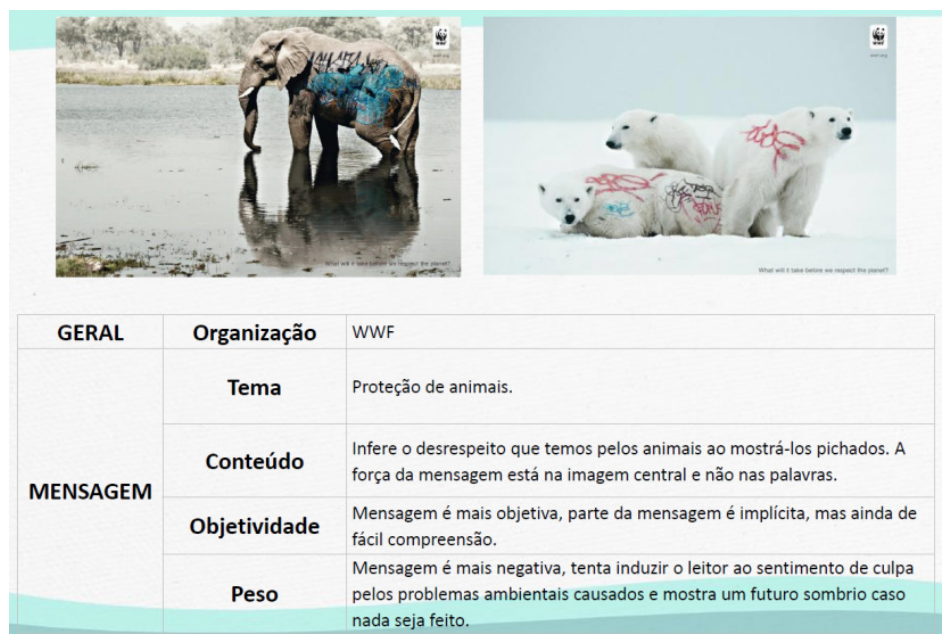

Figura 5 Análise de dois cartazes da WWF

Fonte: NETO et al. 2013

Na fase de síntese do projeto a Equipe decidiu sensibilizar por meio de cartazes informando os problemas da Lagoa, visando mobilizar os moradores para sentir a necessidade de mudar a situação do ambiente e chamar a atenção dos problemas de 
forma simples, usando dados reais e depoimentos dos próprios moradores do lugar. A Figura 6 mostra dois cartazes.
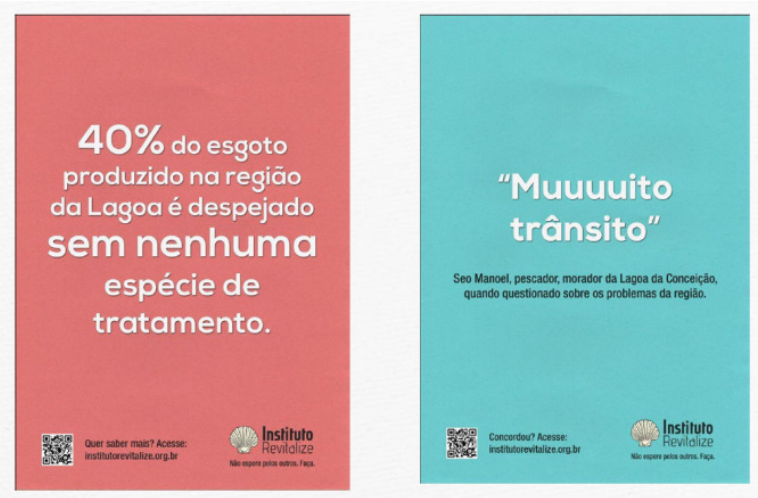

Figura 6 Cartazes

Fonte: NETO et al. 2013

Os alunos relataram que o interesse pelo tema da Lagoa da Conceição veio pelo fato de fazer parte do cotidiano da vida deles, já que são moradores do lugar e se deparam o tempo todo com mau cheiro, proliferação de algas e falta de peixes, alto numero de moradores (densidade demográfica), problemas de mobilidade entre outros. Eles relataram que a experiência de olhar para o entorno e perceber que por meio das ações como futuros designers podem fazer um trabalho que beneficie a comunidade e o local onde vivem foi muito positiva, incluindo o interesse no projeto pela Associação de moradores.

\subsection{Preconceito entre cursos: material de sensibilização}

O tema da Equipe 18 surpreendeu por ser um assunto não mencionado na lista de temas. Durante a fase de pesquisa a equipe percebeu que na universidade havia um pré-conceito entre os diversos cursos tanto entre as profissões quanto entre os alunos. A equipe aplicou questionários com alunos em alguns dos 60 centros da UFSC. A Figura 7 mostra o infográfico com o resultado da pesquisa.

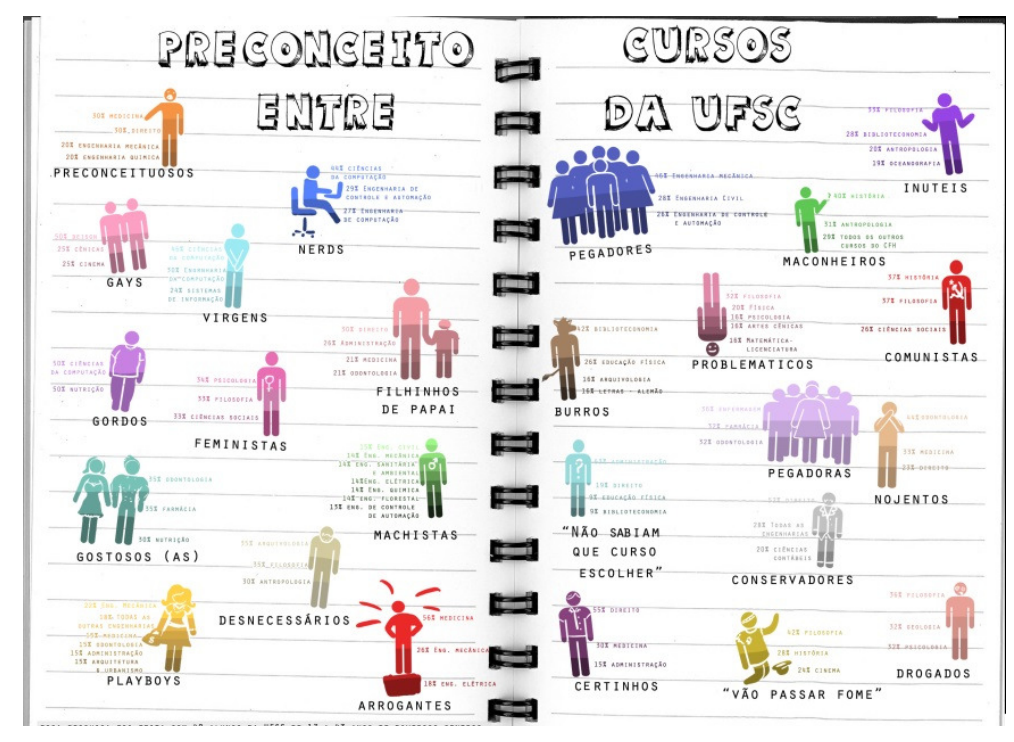

Figura 7 Infográfico

Fonte: CONTEZINI et al. 2013 
A Equipe 18 relatou que foi extremamente divertido presenciar as pessoas respondendo os questionários (especialmente o de relacionar cada aluno do curso a um estereótipo). Perceber as conversas no grupo de amigos e os comentários sobre quais adjetivos já haviam ouvido para seu centro e curso.

As pesquisas da Equipe mostraram dados interessantes como que $95 \%$ dos entrevistados acreditam que existe preconceito entre os cursos, $82 \%$ já ouviram comentários preconceituosos sobre outros cursos, $51 \%$ já sofreram preconceito em relação ao seu curso, $48 \%$ acreditam que o preconceito entre cursos pode prejudicar a carreira profissional no futuro e $43 \%$ conhecem pessoas que desistiram de algum curso devido a sua fama. O curso mais estereotipado segundo a pesquisa é o CFH (centro de filosofia e ciências humanas) e o curso o de Filosofia.

Após a pesquisa com o público a Equipe 18 realizou a pesquisa de concorrentes ou similares, a Figura 8 mostra a análise sincrônica.

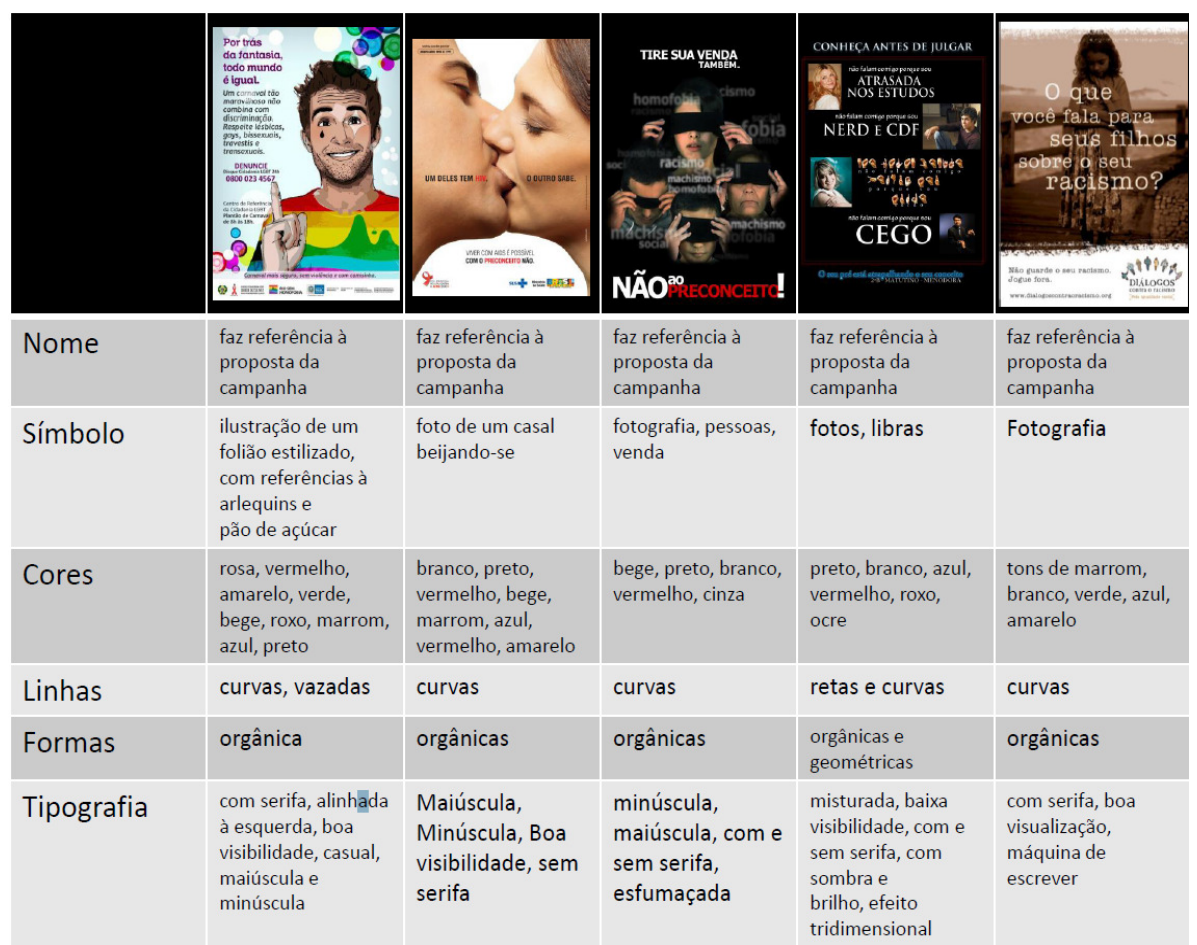

Figura 8 Análise de cinco cartazes sobre preconceito Fonte: CONTEZINI et al. 2013

Na fase de síntese a Equipe decidiu que trabalhariam com o texto "Estereótipos pra quê?", e os principais requisitos eram manter uma forte conexão com o receptor, sensibilizando-o e despertando o questionamento (e mudança) de suas atitudes. Para isso, o conceito foi de adotar um estilo jovem, simples e casual.

Depois de analisadas alternativas geradas, optaram por um modelo simples e jovem, que procurasse passar a mensagem rapidamente e sem complicações.

O grupo relatou ter tido um crescimento significativo, pois durante o processo vários desafios apareceram, forçando-as a mudar as ideias iniciais. Perceberam a importância da aplicação de técnicas e ferramentas de projeto já que direcionaram as decisões. A Figura 9 mostra os cartazes desenvolvidos pela Equipe 18. 


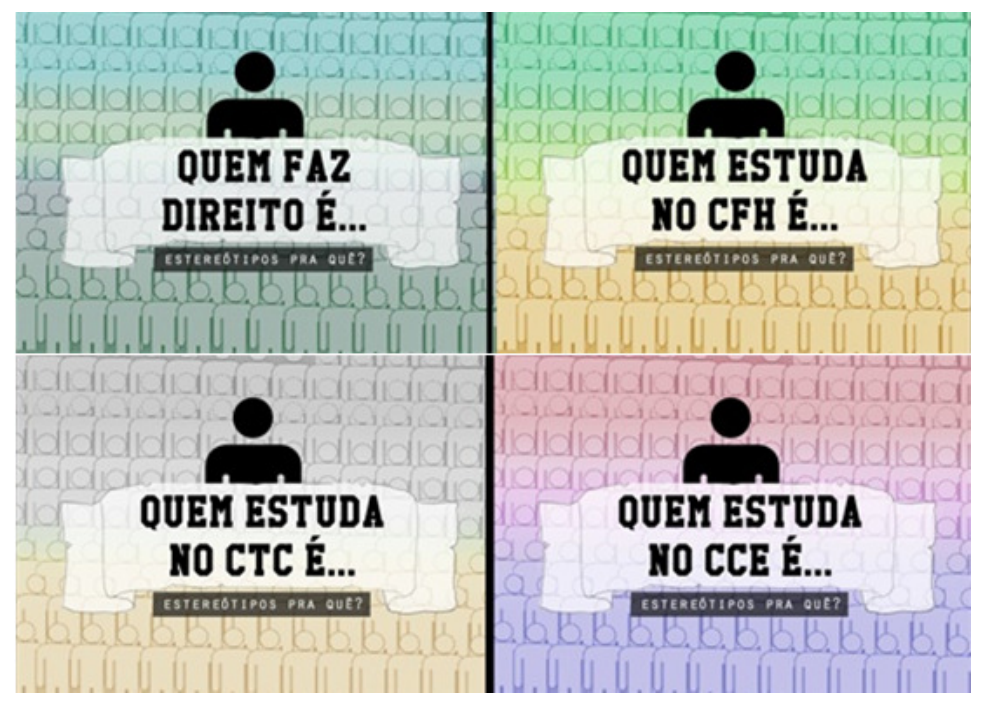

Figura 9 Quatro cartazes sobre preconceito

Fonte: CONTEZINI et al. 2013

O projeto da Equipe 18 foi bastante interessante, já que despertou o olhar do grupo para o entorno e apresentar uma problemática que fica velada no campus. Por outro lado, a equipe demonstrou empatia com o tema o que permitiu que o desenvolvimento fosse prazeroso.

Os 21 projetos desenvolvidos pela turma foram apresentados e avaliados, em relação ao uso adequado das ferramentas e técnicas de projeto passadas na disciplina, como na coerência projetual das decisões tomadas. Cabe salientar que a disciplina de Metodologia de projeto não é de projeto, mas no entendimento da autora deste artigo as técnicas e ferramentas devem ser aplicadas para serem compreendidas e entendidas visando que o aluno apreenda e não apenas aprenda.

\section{CONCLUSÃO}

O artigo apresentado mostrou a aplicação da estratégia de ensinagem por projeto e o resultado do incentivo de design social e ambiental em alunos de fase inicial no curso de Design.

A pesquisa inicial sobre as problemáticas fez pensar aos alunos que não poderiam fazer nada a respeito, devido à complexidade e percepção de que uma pessoa não pode mudar algo tão complexo sozinho. Este pensamento é uma das causas da manutenção de problemas sociais e ambientais. O resultado mostra que a aplicação da estratégia de ensinagem por projeto foi muito positiva, já que fez com que os alunos começassem a refletir e procurar pequenas soluções por meio da sua prática para essas problemáticas. Isso possibilitou que possam começar a mudar a situação vigente, e perceber que unindo pequenas ações pode-se atingir uma grande mudança.

Cabe ao professor ser o agente motivador para que os educandos do curso de design pensem em como favorecer uma transição que atinja o objetivo sustentável, um processo articulado de qualidade social, econômica e ambiental, que é complexo, mas nas palavras de Manzini no "código genético" do Design está registrada a ideia de que sua razão de ser é melhorar a qualidade do mundo. 
Os designers têm como manifestava Papanek uma responsabilidade social e ambiental. Porém, é durante o aprendizado da profissão que o individuo desenvolve as habilidades, capacidades e sensibilidades de designer para atuar no mercado, no mundo e no ambiente. É necessário que o designer seja formado no ensino superior para perceber a realidade e tente por meio do seu conhecimento e habilidades solucionar problemas e não fazer parte deles.

\section{REFERÊNCIAS}

ALESCwww.agenciaal.alesc.sc.gov.br/index.php/noticia single/deputados-cobramsolucoes-para-problemas-ambientais-na-lagoa-da-conceicaeo. Acesso em 10/04/2013

ANASTASIOU, Léa das Graças Camargos. Ensinar, aprender, apreender e processos de ensinagem. In. Processos de ensinagem na universidade: pressupostos para as estratégias de trabalho em aula. / organizado por ANASTASIOU e ALVES. 6. ed.Joinville, SC : UNIVILLE, 2006.

CONTEZINI, Eduarda L; LOCATELLI, Isadora T; LINO, Olívia M. Preconceito entre cursos. Relatório de projeto da disciplina de metodologia de projeto. UFSC. Florianópolis. 2013.

G1 www. g1.globo.com/politica/noticia/2011/05/brasil-tem-1627-milhoes-de-pessoasem-situacao-de-extrema-pobreza.html acesso em 03/05/2013.

GOBBI, Chaiane; SANTOS dos, Diogo; RUTHER, Martina. Material para sensibilizar as pessoas sobre os fatores que influenciam a pobreza. Relatório de projeto da disciplina de metodologia de projeto. UFSC. Florianópolis. 2013.

GUATTARI, Félix. As três ecologias. Papirus, 2007.

MANZINI, Ezio. Design para inovação social e sustentabilidade. Rio de Janeiro. epapers, 2008.

MASETTO, Marcos T. Atividades pedagógicas no cotidiano da sala de aula universitária: reflexões e sugestões práticas. In Temas e textos em metodologia do ensino superior. Organizado por CASTANHO, Sergio e CASTANHO, Maria Eugenia. Papirus Editora, 83102 pp. 2001.

McDONOUGH, William; BRAUNGART, Michael. Cradle to Cradle (De lacuna a lacuna) rediseñando la forma em que hacemos las cosas. Mc GrawHill. Madrid, 2005.

NETO, Agenor; COSTA, Bárbara C; VOLTOLINI, Isis; BRAGA, Nayara. Material para sensibilizar sobre a poluição da Lagoa da Conceição. Relatório de projeto da disciplina de metodologia de projeto. UFSC. Florianópolis. 2013.

PAPANEK, Victor. Design para el mundo real: Ecologia humana e cambio social. Madrid: Ediciones Blume, 1977.

Arquitetura e design: ecologia e ética, Edições 70: Lisboa, 1995.

PAZMINO, Ana Veronica. Modelo de ensino de métodos de design de produtos. Tese (doutorado) - PUC-Rio, Departamento de Artes e Design, Rio de Janeiro, 2010.

Como se cria: 40 métodos de design de produtos. Editora Blücher: São Paulo, 2013. 